\title{
Pengembangan Keterampilan Proses Sains Melalui Metode Penemuan
}

\author{
Weni Astari \\ Pendidikan Biologi Universitas Sains Cut Nyak Dhien Langsa, Aceh \\ Email : weniastari27@gmail.com
}

\begin{abstract}
Abstrak: bertujuan untuk mengetahui perbedaan tingkat keterampilan proses sains dasar siswa yang diajarkan dengan pembelajaran penemuan terbimbing dan penemuan bebas dengan siswa yang diajarkan dengan pembelajaran konvensional. Populasi dalam penelitian ini adalah seluruh siswa kelas XI IPA, di SMAN 1 Dewantara Kreung Geukuh Aceh Utara yang terdiri dari 8 kelas XI IPA, jumlah siswa kelas XI IPA sebanyak 240 siswa, sedangkan sampel penelitian yang berjumlah 90 siswa yang terbagi ke dalam 3 kelas paralel dengan jumlah siswa pada masing-masing kelas 30 siswa. Metode penelitian ini bersifat kuasi eksperimen dengan teknik analisis data menggunakan uji anakova. Hasil penelitian ini diperoleh bahwa terdapat perbedaan tingkat keterampilan proses sains dasar siswa yang diajarkan dengan pembelajaran penemuan terbimbing dengan siswa yang diajarkan dengan pembelajaran konvensional (Fhitung $=34.488 ; \mathrm{P} .=0.000$ ).
\end{abstract}

Kata Kunci: Metode Pembelajaran Penemuan Terbimbing dan Bebas, Keterampilan Proses Sains Dasar Siswa

\section{PENDAHULUAN}

Hakikat pendidikan biologi sebagai sains memiliki tiga dimensi sasaran, yaitu dimensi proses, produk, dan sikap yang tidak dapat dipisahkan dan diabaikan dalam proses belajar mengajar sains. Pembelajaran sains tidak hanya mengembangkan aspek pengetahuan, namun juga harus mengembangkan keterampilan proses dan sikap (Wenno, 2008). Pendidikan sains sangat berhubungan dengan kinerja ilmiah yang dapat dikembangkan melalui hands on atau pengalaman langsung dengan penyelidikan dan percobaan untuk melatih keterampilan proses sains untuk menghasilkan pengetahuan minds on (Rusmiyati \& Yulianto, 2009).

Perubahan mindset pendidikan biologi Indonesia pada kurikulum 2013 disebutkan bahwa biologi berkaitan dengan cara mencari tahu dan memahami alam secara sistematis. Pendidikan biologi bukan hanya sekedar penguasaan sekumpulan pengetahuan yang berupa fakta, pemahaman konsep dan prinsip namun juga merupakan proses penemuan yang didasarkan pada kenyataan yang ada di alam. Berdasarkan Permendikbud No. 65 tahun 2013 tentang standar proses menyebutkan bahwa sasaran pembelajaran mencakup pengembangan ranah keterampilan, pengetahuan dan sikap. Biologi sebagai sains mengedepankan ketiga aspek minds on, hands on dan hearts on yaitu kemampuan menggunakan pikiran untuk membangun konsep melalui pengalaman langsung yang disertai dengan sikap ilmiah (Kemendikbud, 2012).

Berdasarkan "21st Century Partnership Learning Framework", terdapat beberapa kompetensi yang harus dimiliki oleh sumber daya manusia abad 21, yaitu kemampaun memecahkan masalah (Problem Solving Skills) dan kemampuan berkomunikasi (Communication Skills) (Partnership for 21st century Skill, 2002). Tan (2005) menyatakan bahwa pendidikan di zaman ini berhubungan erat dengan masalah yang ada di dunia nyata sehingga pendidik diharapkan tidak hanya menanyakan "bagaimana" tetapi "mengapa" agar peserta didik mampu menemukan konsep sendiri untuk mengatasi masalah.

Keterampilan proses sains merupakan keterampilan yang melibatkan segenap kemampuan siswa dalam memperoleh pengetahuan berdasarkan fenomena. Kemampuan siswa yang dimaksud adalah keterampilan mengamati, mengelompokkan, menafsirkan, memprediksi, mengajukan pertanyaan, berhipotesis, merencanakan percobaan, menggunakan alat dan bahan, menerapkan konsep, berkomunikasi dan melaksanakan percobaan (Rustaman, 2005). Keterampilan proses sains penting dalam pembelajaran saat ini karena, perkembangan ilmu pengetahuan dan teknologi berlangsung semakin cepat sehingga tidak mungkin lagi guru mengajarkan semua konsep dan fakta pada siswa, adanya kecenderungan bahwa siswa lebih memahami konsep-konsep yang rumit dan abstrak jika disertai dengan contoh yang konkret, penemuan dan perkembangan ilmu pengetahuan dan teknologi tidak bersifat mutlak, tapi bersifat relatif, dalam proses belajar mengajar, pengembangan konsep tidak terlepas dari pengembangan sikap dan nilai dalam diri anak didik (Semiawan, 1992).

Penerapan model pembelajaran yang tepat dapat mempengaruhi kualitas belajar siswa. 
Berdasarkan (RPP) guru kurang memvariasi model pembelajaran yang diterapkan pada kelas dan masih berorientasi pada hasil belajar sehingga keterampilan proses terabaikan, walaupun pembelajaran Biologi diorientasikan pada hasil namun rata-rata hasil belajar Biologi di SMA Jumapolo belum sesuai yang diharapkan yaitu 70,78 < 75,00. Pembelajaran Biologi harus mampu mencakup permasalahan dan memenuhi aspek proses, produk dan sikap. Masalah pembelajaran merupakan masalah kompleks yang melibatkan berbagai aspek termasuk siswa, guru, kegiatan mengajar, media belajar dan sebagainya. Menurut Slameto (2010) salah satu faktor ekstern yang mempengaruhi hasil belajar adalah metode pembelajaran yang dapat diterapkan melalui suatu model pembelajaran tertentu.

Model pembelajaran yang tepat untuk pembelajaran Biologi sebagaimana seharusnya yang mampu memberi kesempatan siswa berperilaku ilmiah dan memenuhi tuntutan keterampilan abad-21 adalah Problem Based Learning. Menurut Arends (2007) Model tersebut merupakan pembelajaran yang berorientasi pada masalah dan pemecahannya di dalam kelas. Ciri utama model pembelajaran ini adalah bahwa pengetahuan dicari dan dibentuk oleh siswa dalam upaya memecahkan contohcontoh masalah yang dihadapkan pada mereka sebagai subjek yang melakukan aktivitas belajar, siswa tidak berperan sebagai penerima informasi pasif, tetapi diarahkan untuk menemukan informasi yang relevan dan merancang solusi atas permasalahan yang ada sehingga Problem Based Learning menurut Tosun \& Senocak (2013) dapat menciptakan suasana pengetahuan metakognisi yaitu siswa dapat berfikir bagaimana cara berfikir dan siswa dapat mengontrol proses kognisinya sendiri.

Keterampilan proses sains dapat terlatihkan karena terjadi aktivitas ilmiah pada pembelajaran, menurut Masek \& Sulaiman (2011) Problem Based Learning dapat membuat siswa berfikir kritis/tingkat tinggi. Keterampilan proses sains akan dikuasai siswa jika siswa mampu berfikir tingkat tinggi (Meyers, Washburn \& Dyer, 2004). Problem Based Learning menurut ahli tersebut dapat mempengaruhi pengetahuan yang didapatkan siswa mencapai kemampuan metakognisi dan membuat siswa berfikir tingkat tinggi sehingga keterampilan proses sains dapat dikuasai siswa, dengan kata lain pengetahuan dan keterampilan proses sains siswa dapat meningkat.

Siswa yang berubah pengetahuannya maka keterampilan dan sikap juga akan berubah
(Slameto, 2010). Batdi (2014) menyatakan bahwa Problem Based Learning dapat meningkatkan sikap pada pembelajaran. Jadi Problem Based Learning dapat meningkatkan pengetahuan, keterampilan proses sains dan sikap.

Problem Based Learning diharapkan memenuhi kebutuhan abad-21 yaitu problem solving skills dan communication skills yang dapat dilaksanakan pada sintaks ke-3 (membantu siswa meneliti) dan ke-4 (memamerkan hasil karya). Problem Based Learning diharapkan dapat meningkatkan keterampilan proses sains dan hasil belajar ranah pengetahuan dan sikap siswa.

\section{METODE PENELITIAN}

Penelitian ini dilaksanakan di SMAN 1 Dewantara Kreung Geukuh Aceh Utara. Pada semester ganjil tahun pelajaran 2013/2014. Waktu penelitian sekitar bulan Juni - Agustus 2013. Dalam rentang waktu ini sudah termasuk kegiatan survei pendahuluan, penyusunan proposal penelitian, uji coba instrumen, pengumpulan data, analisis data, dan penulisan laporan penelitian. Populasi adalah keseluruhan subjek penelitian apabila seseorang ingin meneliti semua elemen yang ada dalam wilayah penelitian, maka penelitiannya merupakan penelitian populasi (Arikunto, 2006). Jadi berdasarkan tujuan penelitian ini maka populasi dalam penelitian adalah semua siswa kelas XI IPA, di SMAN 1 Dewantara Kreung Geukuh Aceh Utara yang terdiri dari 8 kelas XI IPA, jumlah siswa kelas XI IPA sebanyak 240 siswa. sampel penelitian sebanyak tiga kelas yang ditentukan dengan menggunakan tehnik pengambilan secara acak (Random Sampling) sebagai kelas perlakuan, yaitu: a.Kelas yang dibelajarkan dengan metode konvensional, (30 Siswa). b. Kelas yang dibelajarkan dengan (kelas XI IPA mandiri ${ }_{2}$ ) metode penemuan terbimbing, (30 Siswa). c. Kelas yang dibelajarkan dengan (kelas XI IPA mandiri ${ }_{1}$ ) metode penemuan bebas, (30 Siswa). Variabel dalam penelitian ini ada dua jenis, yaitu: variabel bebas dan variabel terikat. Jenis penelitian yang dilakukan adalah eksperimen semu (quasi eksperimental research).

\section{Teknik Pengumpulan Data}

Teknik pengumpulan data pada penelitian ini adalah dengan teknik non tes berupa angket, yaitu sejumlah pernyataan tertulis tentang 
keterampilan proses sains dasar siswa berupa tes pilihan ganda berjumlah 8 soal.

\section{Teknik analisis data}

Teknik analisis data yang digunakan dalam Penelitian ini adalah teknik analisis berupa analisis deskriptif dan analisis inferensial. Teknik analisis deskriptif dimaksudkan untuk mendeskripsikan data penelitian meliputi ratarata, median, modus, varians dan standar deviasi. Uji normalitas dilakukan dengan pendekatan

Kolmogorov-Smirnov.

Uji homogenitas data dilakukan pendekatan Levene's Test. Setelah prasyarat terpenuhi selanjutnya dilakukan pengujian hipotesis penelitian dengan menggunakan Analisis Kovariat (ANACOVA). Apabila hasil uji statistik menunjukkan pengaruh yang signifikan, maka analisis dilanjutkan dengan uji Tukey's pengolahan data dilakukan dengan menggunakan SPSS.19.0.

\section{HASIL DAN PEMBAHASAN}

Tabel 1. Deskripsi Keterampilan Proses Sains Siswa

\begin{tabular}{lllll}
\hline No. & Metode & $\begin{array}{l}\text { Rata-rata Skor } \\
\text { Keterampilan Proses Dasar } \\
\text { Sains Siswa }\end{array}$ & Standard Deviasi & $\begin{array}{l}\text { Standard } \\
\text { Error }\end{array}$ \\
\hline 1. & Penemuan Terbimbing & 87,39 & 5,85 & 1,06 \\
2. & Penemuan Bebas & 85,21 & 7,36 & 1,34 \\
3. & Konvensional & 75,65 & 9,24 & 1,68 \\
\hline
\end{tabular}

\section{Normalitas Data}

Berdasarkan hasil uji normalitas data, maka secara keseluruhan data berdistribusi normal dengan nilai signifikan $>0,05$.

\section{Homogenitas Data}

Berdasarkan hasil uji homogenitas data, maka secara keseluruhan data bersifat homogen dengan nilai signifikan $>0,05$.

\section{Uji Hipotesis}

Berdasarkan hasil uji hipotesis diperoleh bahwa terdapat perbedaan tingkat keterampilan proses sains dasar siswa yang diajarkan dengan pembelajaran penemuan terbimbing dengan siswa yang diajarkan dengan pembelajaran konvensional (Fhitung $=34.488 ;$ P. $=0.000$ ); serta terdapat perbedaan tingkat keterampilan proses sains dasar siswa yang diajarkan dengan pembelajaran penemuan bebas dengan siswa yang diajarkan dengan pembelajaran konvensional pada SMAN 1 Dewantara Kreung Geukuh Aceh Utara (Fhitung $=19.640 ;$ P. $=$ $0.000)$.

\section{PEMBAHASAN}

Pada hasil Penelitian ini diperoleh bahwa hasil belajar siswa yang diajarkan dengan pembelajaran penemuan terbimbing dan penemuan bebas lebih baik dibandingkan dengan konvensional. Sebagaimana pernyataan menurut Martin (2006), penemuan terbimbing menggabungkan guru yang fokus dalam metodologi ekpositori dengan anak fokus pada metodologi free-discovery. Pada penemuan terbimbing, guru memilih topik dan menetapkan arah. Siswa-siswa bertanya yang nantinya akan menentukan arah yang baru. Guru menyarankan kegiatan open-ended bahwa siswa mengejar untuk menemukannya, menyelidiki apa yang belum mereka pahami, dan membangun kesimpulan mereka sendiri seperti konsep yang mereka bangun. Siswa memeriksa kesimpulan mereka untuk melihat apakah mereka memiliki kemampuan prediksi dan ceramah. Jika demikian, mereka berdiskusi satu sama lain dan dengan guru untuk mengkonfirmasi kevalidasiannya. Jika validitas tidak dapat di konfirmasi, mereka memulai investigasi untuk mengembangkan merevisi kesimpulan dan merekonstruksi konsep. Penemuan terbimbing adalah metode dimana guru sebagai fasilitator dan pengarah sedangkan siswa aktif melakukan kegiatan sesuai prosedur atau langkah kerja untuk mengembangkan rasa ingin tahunya.

Trowbridge \& Bybee (1990) membagi metode penemuan menjadi 2 jenis yaitu: (1) penemuan terbimbing (guided discovery); (2) penemuan bebas (free discovery). Dalam penemuan terbimbing, guru menyediakan data dan siswa diberi pertanyaan atau masalah untuk membantu mereka mencari jawaban, kesimpulan generalisasi dan solusi. Pada penemuan bebas murid merencanakan solusi, mengumpulkan data dan selebihnya sama dengan penemuan terbimbing. Oleh sebab itu metode penemuan yang lebih efektif untuk digunakan untuk menyampaikan materi 
pembelajaran adalah metode penemuan terbimbing. Metode penemuan terbimbing merupakan kegiatan inquiry yang masih membutuhkan keterlibatan guru dalam proses pembelajaran, di mana masalah dikemukakan oleh guru atau bersumber dari buku teks kemudian siswa berpikir untuk menemukan jawaban terhadap masalah tersebut di bawah bimbingan intensif guru.Nasution (1988) mengemukakan bahwa pemecahan masalah adalah suatu metode belajar yang mengharuskan siswa untuk menemukan jawaban tanpa bantuan atau tanpa bimbingan dari guru. Memecahkan masalah dapat dipandang sebagai proses dimana siswa menemukan kombinasi aturan-aturan yang telah dipelajari terlebih dahulu yang digunakan Untuk memecahkan masalah baru. Strategi pembelajaran penemuan bebas dapat digunakan/ditetapkan untuk memecahkan masalah atau untukmenemukan jawaban melalui pengalaman siswa dalam mengkombinasikan konsep dan prinsip yang berkaitan dengan masalah tersebut.

Dengan demikian metode pembelajaran penemuan bebas berorientasi pada siswa untuk aktif, kreatif dan produktif upaya menemukan konsep, prinsip melalui pemecahan masalah, mencoba mencari jawaban atas masalah yang dihadapi dengan mengaitkan pengalaman sebelumnya untuk memperoleh jawaban tersebut. Guru berperan sebagai fasilitator. Siswa memperoleh atau menemukan informasi berdasarkan tindakan mereka dalam melaksanakan kegiatan belajar yang dalam hal ini dipelajarinya dalam menyelesaikan soal-soal karena sikap inovatif tinggi mampu dalam memecahkan masalah-masalah dari gejalagejala yang nyata hingga yang abstrak. Siswa yang memiliki sikap inovatif yang tinggi memiliki imajinasi menghasilkan kemampuan untuk melahirkan gagasan-gagasan baru yang bersumber dari hasil pemikiran sendiri, sehingga siswa tersebut akan mampu melahirkan berbagai gagasan dan berbagai alternatif penyelesaian masalah pembelajaran, mengungkap peluang-peluang baru pembelajaran, juga mampu untuk membangun (mengkonstruksi) keterampilan dan pengetahuan yang dibutuhkan. Karena pengetahuan dan keterampilan yang dimilikinya berdasarkan informasi yang diberikan oleh gurunya bukan karena dibangun atau dikontruksi oleh siswa tersebut.

\section{SIMPULAN}

Terdapat perbedaan tingkat keterampilan proses sains dasar siswa yang diajarkan dengan pembelajaran penemuan terbimbing dan penemuan bebas dengan siswa yang diajarkan dengan pembelajaran konvensional pada SMAN 1 Dewantara Kreung Geukuh Aceh Utara.

\section{DAFTAR PUSTAKA}

Adesoji, A, F. 2008 . Students Ability Levels And Effectiveness Of Problem-Solving Instructional Strategy. Journal Society Science, 17: 5-8.

Akcay, B. 2009 . Problem Based Learning in Science Education. Journal of Turkish Science Education, 6: 26-23.

Akinbobola, A, O and Afolabi. 2010. Constructivist Practices Through Guided Discovery Approach: The Effect in Students' Cognitive Achievement in Nigerian Senior Secondary School Physics. Eurasian Journal of Physics and Chemistry Education. 2: 16-26.

Arikunto, S. 2006. Prosedur Penelitian suatu Pendekatan Praktik. Jakarta: Rineka Cipta.

Balim, A. 2009. The Effects of Discovery Learning on Students' Success and Inquiry Learning Skills. Egitim Arastirmalari-Eurasian Journal of educational Reasearch, 35: 1-20.

Derri and Pachta. 2007. Motor Skills and Concepts Acquisition and Retention: A Comparison Between Two Styles of Teaching. International Journal of Sport Science, 3: 37-34.

Dimyati \& Moedjiono. 2002. Belajar dan Pembelajaran. Jakarta: Rineka Cipta.

Djamarah dan Zain. 2006. Metode Belajar dan Mengajar. Jakarta: Bumi Aksara.

Gulo, W. 2004. Metode BelajarMengajar. Jakarta: Gramedia Widiasarana.

Gulo, W. 2008.Metode Belajar Mengajar. Jakarta: Grasindo.

Gulo, W. 2011.Metode Belajar Mengajar. Jakarta: Grasindo.

Hamalik, O. 2008. Kurikulum danPembelajaran. Jakarta: Bumi Aksara.

Hidayatullah, F, M. 2011. MenjadiGuru Sejati. Makalah disajikan pada Seminar Nasional Himpunan Mahasiswa Pendidikan Biologi (HIMABI) FKIP, Universitas Sebelas Maret, 19 Maret.

Ilmi. 2012. Pengaruh Penerapan Metode Pembelajaran Guided Discovery Terhadap Keterampilan Proses Sains Siswa Kelas X SMA Negeri 1 Teras Boyolali Tahun Pelajaran 2011/2012. Jurnal Pendidikan Biologi, 4:44-52.

Isjoni. 2008 . Pembelajaran Koopertif. Yogyakarta: Pustaka Pelajar.

Joyoatmoyo, S. 2006. Belajar Mandiri: Bekal Untuk Menapak JalanMenuju Belajar Sepanjang Hayat. Makalah disajikan pada kuliah perdana 
bagi mahasiswa baru jurusan Pendidikan Matematika dan Ilmu Pengetahuan Alam, hlm.120. Surakarta: FKIPUniversitas Sebelas Maret.

Melani. 2012. Pengaruh Metode Guided Discovery Learning Terhadap Sikap Ilmiah dan Hasil Belajar Kognitif Biologi Siswa SMA Negeri 7 Surakarta Tahun Pelajaran 2011/2012. Jurnal Pendidikan Biologi, 4: 97-105.

Mulyasa, E. 2006. Kurikulum BerbasisKompetensi, Konsep, Karakteristik,Implementasi dan Inovasi. Bandung: Remaja Rosdakarya.

Orlich, D. C., Harder, R. J., Callahan, R.C., \& Gibson, H. W. 1998. Teaching Metodees A Guided toBetter Instruction. Boston: Houghton Mifflin Company.

Sanjaya, W. 2008. Pembelajaran dalam Implementasi Kurikulum Berbasis Kompetensi. Jakarta: Prenata Media Group.

Sumantri, M., \& Permana, J. 2001. Metode Belajar Mengajar. Bandung: Maulana.
Trianto. 2010. Mendesain Model Pembelajaran Inovatif-Progresif. Jakarta: Kencana.

Usman, U, M. 2008. Menjasi GuruProfesional. Bandung: Remaja Rosdakarya.

Widhiyantoro. 2012. The Effectiveness of Guided Discovery Method Application Toward Creative Thingking Skill at The Tenth Grade Students of SMAN 1 Teras Boyolali in the Academic Year 2011/2012. Jurnal Pendidikan Biologi, 4: 89-99.

Zaini, H. 2009. Metode PembelajaranAktif implementasi dan kendaladi dalam kelas. Makalah disajikan pada Seminar Dan Lokakarya Nasional 'Peningkatan Kualitas Pembelajaran Melalui Aktif Learning MenujuProfesionalisme Guru, Surakarta: FKIP Universitas Sebelas Maret.

Zaini, H., Munthe, B., \& Aryani, S. A. 2008. Metode PembelajaranAktif. Yogyakarta: Insan Madani. 